Indonesian Journal of Biotechnology, December, 2014

Vol. 19, No. 2, pp.99-110

\title{
Molecular Identification of Phenol-Degrading and Biofilm-Forming Bacteria from Wastewater and Peat Soil
}

\author{
Arifah Khusnuryani ${ }^{1,2^{*}}$, Erni Martani ${ }^{3}$, Tri Wibawa ${ }^{4}$, Jaka Widada ${ }^{3}$
}

\author{
${ }^{1}$ Biotechnology Study Program, Universitas Gadjah Mada, Yogyakarta, Indonesia \\ ${ }^{2}$ Biologi Study Program, UIN Sunan Kalijaga, Yogyakarta, Indonesia \\ ${ }^{3}$ Faculty of Agriculture, Universitas Gadjah Mada, Yogyakarta, Indonesia \\ ${ }^{4}$ Faculty of Medical, Universitas Gadjah Mada, Yogyakarta, Indonesia
}

\begin{abstract}
Phenol is hazardous aromatic pollutant which needs to be treated to reduce its hazardous effects. Bioremediation using bacteria which can form biofilm offer an alternative wastewater treatment that is cheaper and environmentally safe. Eighteen strains of phenol-degrading and biofilm-forming bacteria were isolated from peat soil, also hospital and textile wastewater. Screening for phenol degradation ability of isolates were performed using Folin-ciocalteau reagent, while for biofilm formation ability were performed using microtiter plate and crystal violet dye. Based on the ability to degrade phenol and to form biofilm, four isolates (HP3, DOK135, DL120, andATA6) were choosen as phenol-degrading bacteria as well as biofilm-forming bacteria. Based on phenotypic and genotypic characterization, isolate HP3 was highly similar to Rhodococcus equi strain DSM20307T, while DOK135 was highly similar to Enterobacter mori strain R18-2.The results also suggested that DL120 and ATA6 could be classified to the genus of Micrococcus and Bacillus respectively.
\end{abstract}

Keywords: biofilm-forming bacteria, phenol-degrading bacteria, phenotypic and genotypic characterization

\section{Introduction}

Phenols is an aromatic organic compound that occurs naturally in the environment (Ying et al., 2007), for example in peat soil (Barchia, 2006; Agus and Subiksa, 2008). However, phenols are more commonly produced as artifical aromatic compounds in wastewater from many industries, such as textile, dye, oil refinery, chemical instalation, and medical (Lee et al., 1997; Tsai et al., 2005; Al-Thani et al., 2007; Anonim, 2008). Phenol is relatively soluble in water, and the wastewater containing this compound can contaminate and accumulate in soil, surface water, and ground water (Zaki, 2006; Mahiuddin et al., 2012). This corrosive compound can be absorbed through inhalation, digestion,

*Corresponding author:

Arifah Khusnuryani

Biologi Study Program, UIN Sunan Kalijaga,

Yogyakarta, Indonesia

Email: anikarifah@yahoo.com also skin, and may cause chemical burn, promotes tumor (Bitton, 2005; Anonim, 2008; Chakraborty et al., 2010), also affect the function of human and animal hormonal system (Aoyama et al., 2012).

Due to its hazardous effects, appropriate phenolic wastewater treatment is needed and biological wastewater treatment using microbe activities or bioremediation is an appealing option. The method is considered effective for environmental decontamination (Tsai et al., 2005), considerably cheap, environmental friendly, and less sideproduct (Al-Thani et al., 2007; Bayoumi and Ashraf, 2010). Moreover, by using this method, pollutant is degraded completely or at least changed into less harmful products (Mahiuddin et al., 2012). Those conditions happen because microbes use phenol as a source of carbon and break it into $\mathrm{CO}_{2}$ (Amro and Soheir, 2007; Tuah et al., 2009).

Some researchers reported that some microbes can degrade phenols, such as 
Acinetobacter PD12 isolated from active sludge of wastewater treatment (Ying et al., 2007), Pseudomonas putida (Movahedyan et al., 2009) and Streptococcus epidermis (Mohite et al., 2010). Phenol-degrading bacteria can be isolated from natural and artificial sources. Sediment of drainage ditch and river (Van Schie and Young, 1998), and soil (Amro and Soheir, 2007; Wang et al., 2007) are some examples of natural sources of phenoldegrading bacteria. Meanwhile, the artificial sources for the bacteria include industrial and municipal wastewater (Mailin and Firdausi, 2006; Khuanmar et al., 2007; Ying et al., 2007; Movahedyan et al., 2009; Chakraborty et al., 2010), as well as soil around industrial area or soil contaminated by industrial wastewater (Tsai et al., 2005; Al-Thani et al., 2007; Agarry et al., 2009; Mohite et al., 2010). According to El-Sayed et al. (2003) and Ying et al. (2007), aerobic phenol-degrading bacteria that degrade phenols at some concentrations are still needed.

In general, bacteria in nature will grow and form biofilm, which immobilize bacterial consortium on a surface of substrate in aquoeus environment (Davey and $\mathrm{O}^{\prime}$ toole, 2000). Biofilm-forming bacteria have some advantages, such as able to survive in less advantage environment and able to spread to form new colonies in new niches (Martinez and Casadevall, 2007). They also improve the degradation of recalcitrant compounds, because bacteria interact with each other and complete the metabolic processes (Andersson, 2009). Some studies of biofilm in waste treatment have been conducted, such as biofilm formation in wastewater (Dumitru et al., 2008), biofilm formation on some materials (Andersson et al., 2008), and biofilm formation by chlorobenzoatdegrading bacteria (Yoshida et al., 2009).

According to the explanation above, it is obvious that phenol is hazardous for the environment and health, then appropriate technology is needed to cope that problem. On the other side, it is known that biofilm has important role in wastewater treatment.
Therefore, this research is focused on isolation and identification of bacteria that degrade phenol as well as form biofilm. Having known the character and the identity of phenol-degrading as well as biofilm-forming bacteria, the selected bacteria can be used to improve the effectiveness of phenolic wastewater treatment.

\section{Material and Methods \\ Isolation of Phenol-Degrading Bacteria}

Peat soil was used as a natural source for phenol degrading bacteria, while bacteria from artificial sources were isolated from hospital and textile wastewater. Enrichment culture technique using Ramsay medium was applied to isolate bacteria. The Ramsay medium $\left(\mathrm{NH}_{4} \mathrm{NO}_{3} 2 \mathrm{~g} ; \mathrm{KH}_{2} \mathrm{PO}_{4} 0,5 \mathrm{~g} ; \mathrm{K}_{2} \mathrm{HPO}_{4}\right.$ $1 \mathrm{~g} ; \mathrm{MgSO}_{4} .7 \mathrm{H}_{2} \mathrm{O} 0,5 \mathrm{~g} ; \mathrm{CaCl}_{2} \cdot 2 \mathrm{H}_{2} \mathrm{O} 0,01 \mathrm{~g} ; \mathrm{KCl}$ $0,1 \mathrm{~g}$; aquadest $1 \mathrm{~L}$ ) was added with phenol and glucose in gradual concentration. First, the sample was added into Ramsay broth medium supplemented with $1 \mathrm{~g} / \mathrm{L}$ of glucose and incubated on rotary shaking incubator at $125 \mathrm{rpm}$ for 24 hours. Afterwards, the media was transferred into freshly prepared Ramsay broth media supplemented with 100 $\mathrm{mg} / \mathrm{L}$ of phenol and glucose $0,5 \mathrm{~g} / \mathrm{L}$, and then incubated in a room temperature for a week at $125 \mathrm{rpm}$. Similar procedure was then applied each week, using Ramsay broth media supplemented with a combination of $300 \mathrm{mg} / \mathrm{L}$ of phenol and $0,25 \mathrm{~g} / \mathrm{L}$ of glucose, continued by a combination of $500 \mathrm{mg} / \mathrm{L}$ of phenol and 0,125 $\mathrm{g} / \mathrm{L}$ of glucose. At the end of the incubation, the sample was inoculated into Ramsay agar medium containing $500 \mathrm{mg} / \mathrm{L}$ of phenol, using spread plate method. The single colonies were streaked onto similar medium to obtain pure isolates of phenol-degrading bacteria.

\section{Phenol Degradation Ability Test}

Isolates were grown in Nutrien Broth (NB) medium for 24 hours at $125 \mathrm{rpm}$. Then, the number of bacteria was accounted by plate count method. Inoculum of bacteria $\left(10^{6} \mathrm{cell} / \mathrm{mL}\right)$ was added into Ramsay medium containing 300 ppm of phenol, followed by 
incubation for 96 hours at 125 rpm. Every 24 hours, the residu of phenols and bacterial growth were analyzed.

Analysis of phenol residu was conducted according to Vermerris and Nicholson (2006). Sampel was centrifuged at $10.000 \mathrm{rpm}$ for 10 minutes. Then, supernatan was added with 0,3 $\mathrm{mL} \mathrm{NaCO}_{3}(200 \mathrm{~g} / \mathrm{L})$ and after mixing, 0,1 $\mathrm{mL}$ of Folin-ciocalteau reagent was added. The sample was left for 30-60 minutes in room temperature, and then the absorbance was measured with spectrophotometer at $750 \mathrm{~nm}$.

\section{Biofilm Formation Ability Test}

The assessment of biofilm formation ability was modified from Djordjevic et al. (2002), Mathur et al. (2006) and Merritt et al. (2011). The isolate of phenol-degrading bacteria $\left(10^{6} \mathrm{CFU} / \mathrm{mL}\right)$ was inoculated in TSB medium and incubated at room temperature for 24 hours at $125 \mathrm{rpm}$. Then, the isolate was added into four wells of microtiter plate $(100 \mu \mathrm{L}$ each). Microtiter plate was sealed and incubated for 24 and 48 hours in room temperature. Then, the isolates were removed and the plate was washed with aquadest. Each well was added with 125 $\mu \mathrm{L}$ of $0,1 \%$ crystal violet solution, and left for 10 minutes in room temperature. After the crystal violet solution was removed, the plate was washed with aquadest and dried in inverse position for 1-2 weeks.

For quantitative analysis, each well was added by $200 \mu \mathrm{L}$ of PBS. After stored at room temperature for 10-15 minutes, the solution was mixed by pipetting several times. Then, $125 \mu \mathrm{L}$ of sampel was transferred to a new microtiter plate and the crystal violet solution was measured with micro Elisa auto reader at $490 \mathrm{~nm}$. Biofilm formation ability was classified according to Møretrø et al. (2003). Sample would be classified as weak former if $\mathrm{A}_{490}<0,20$; medium former if $0,20 \leq$ $\mathrm{A}_{490} \leq 1,0$; and strong former if $\mathrm{A}_{490}>1,0$.

\section{Identification of Isolates}

The isolated bacteria showing high ability in phenol degradation and biofilm formation were identified based on phenotypic and genotypic characterization. Phenotypic characterization was performed by examining colony morphology, cell morphology, motility, spore formation, and some biochemical characteristics of isolates. Genotypic characterization was conducted by $16 \mathrm{~S}$ rDNA sequence comparison.

\section{Molecular Identification}

Isolate was inoculated in Nutrient Broth medium for 24 hours at room temperature and then, $5 \mathrm{~mL}$ inoculum was transferred into sterile tube and sentrifuged at 3000 rpm for 20 minutes. The pellet was added with $1 \mathrm{~mL}$ buffer lysis and $10 \mathrm{mg} / \mathrm{mL}$ protein precipitation solution, followed by homogenization and incubation at $55^{\circ} \mathrm{C}$ for 30 minutes. After the suspension was sentrifuged at $13.000 \mathrm{rpm}$ for 10 minutes, the supernatant was added with chloroform 1:1 and homogenized using shaker at low speed for 15 minutes, continued by centrifugation at $13.000 \mathrm{rpm}$ for 10 minutes. Supernatan was transferred into a new sterile microtube, added with absolute ethanol 1:1, and incubated at $-20^{\circ} \mathrm{C}$ for 1 hour. Afterwards, the suspension was centrifuged again at $13.000 \mathrm{rpm}$ for 10 minutes. After the supernatant was removed, the pellet was washed with $70 \%$ etanol, and then dried in room temperature for 1-2 hours. The dried pellet was resuspended with 40 $\mu \mathrm{L}$ buffer TE and RNase $3 \mu \mathrm{L}$, and then incubated in waterbath at $37^{\circ} \mathrm{C}$ for 1 hour.

Amplification was performed by mixing $1 \mu \mathrm{L}$ of DNA, $5 \mu \mathrm{L}$ of Ready To Go Mixture PCR, $22 \mu \mathrm{L}$ of $\mathrm{ddH}_{2} \mathrm{O}, 1 \mu \mathrm{L}$ of primer $27 \mathrm{~F}$ $(10 \mathrm{pmol} / \mu \mathrm{L})$ and $1 \mu \mathrm{L}$ of primer $1429 \mathrm{R}$ $(10 \mathrm{pmol} / \mu \mathrm{L})$. Early denaturation was conducted at $95^{\circ} \mathrm{C}$ for 5 minutes, followed by 30 cycles of denaturation $\left(94^{\circ} \mathrm{C}, 30\right.$ seconds), annealing $\left(52^{\circ} \mathrm{C} ; 1,5\right.$ minutes $)$, and extension $\left(72^{\circ} \mathrm{C}, 1\right.$ minute). Final extension was carried out at $72^{\circ} \mathrm{C}$ for 5 minutes, followed by $4^{\circ} \mathrm{C}$ hold. Electroforesis of the PCR products was conducted in a $0,8 \%$ agarose. The appearance of $\pm 1,5 \mathrm{~kb}$ band showed that $16 \mathrm{~S}$ rDNA had been amplified and ready for sequencing. 
Sequencing was carried out at 1st BASE Malaysia. For the identification, $16 \mathrm{~S}$ rDNA sequence was searched against all sequences in the NCBI databases using BLASTN program (www.ncbi.nih.nlm.gov/Blast.cgi). The sequences of $16 S$ rDNA were analyzed by multiple alignments using CLUSTAL $X$ Windows Interface programe. Phylogenetic tree depicted phylogenetic classification of bacteria was constructed using PHYDIT and PHYLIP programe (Ying et al., 2007).

\section{Results and Discussion Isolation of Phenol-Degrading Bacteria}

Phenol-degrading bacteria can be isolated from natural sources as well as sources that produced phenol artificially. In this study, peat soil was used as natural source, while hospital and textile wastewater was used as artificial sources of phenol degrading bacteria. Isolation was conducted by enrichment method using Ramsay medium (minimal medium) containing gradual increasing of phenol concentration combined with gradual decreasing of glucose concentration. Those gradual concentrations were set up for tolerant bacteria to grow well in a high number. Watanabe et al. (1998) recommended using many kinds of methods to isolate microbe from a complex microbial community. However, direct plating and enrichment are more recommended to isolate bacterial population from environment.

Next screening was carried out by inoculated the isolate in Ramsay medium with varying concentration of phenol from 1000 to $10.000 \mathrm{mg} / \mathrm{L}$. Phenol was the solely source of carbon in the medium, hence bacteria grown in the medium could be predicted as highly tolerance to phenol and able to degrade phenol. At this step, we obtained 18 isolates that tolerance to 10.000 $\mathrm{mg} / \mathrm{L}$ of phenol (Tabel 1).

Table 1 shows that 9 isolates were able to reduce phenol up to $75 \%$ and over. Four isolates were obtained from hospital wastewater (DL120, DOK135, ATA6, and AS1), one isolate from textile industry
Table 1. Phenol degrading ability of isolates from natural and artificial sources

\begin{tabular}{cccc}
\hline No & Isolate & Source & $\begin{array}{c}\text { Phenol } \\
\text { reduction }(\%)\end{array}$ \\
\hline 1 & DL120 & Hospital wastewater & 96,350 \\
2 & DOK135 & Hospital wastewater & 94,67 \\
3 & TU3 & Textile industry & 92,29 \\
& & wastewater \\
4 & HP3 & Peat soil & 90,88 \\
5 & HG1 & Peat soil & 89,31 \\
6 & SG3 & Peat soil & 86,87 \\
7 & SG1 & Peat soil & 86,500 \\
8 & ATA6 & Hospital wastewater & 79,030 \\
9 & AS1 & Hospital wastewater & 75,300 \\
10 & TP1 & Textile industry & 49,000 \\
& & wastewater & \\
11 & AS3 & Hospital wastewater & 28,440 \\
12 & HG2 & Peat soil & 26,930 \\
13 & ATA2 & Hospital wastewater & 23,500 \\
14 & ATA3 & Hospital wastewater & 14,940 \\
15 & DOK144 & Hospital wastewater & 9,500 \\
16 & SG2 & Peat soil & - \\
17 & ATA4 & Hospital wastewater & - \\
18 & ATA7 & Hospital wastewater & - \\
\hline
\end{tabular}

wastewater (TU3), and four isolates from peat soil (HP3, HG1, SG3, and SG1). It can be seen that phenol-degrading bacteria can be obtained from natural and artificial sources. Phenol degradation ability of isolate SG2, ATA4, and ATA7 was not measured because those three isolates were not well grown. Therefore, it is assumed that those isolates have low ability to grow in medium with phenol as a solely source of carbon, which also means that the isolates have low ability in degrading phenol.

Wastewater was choosen as the source of isolates, therefore, the isolates will not need adaptation or only need minimum adaptation when applied for phenolic wastewater treatment. Vogel and Michael (2002), stated that there is a limitation in application of bioaugmentation, which is the low survival ability of microbes using for wastewater treatment. Thus, the usage of indigenous bacteria from wastewater can reduce that limitation. Another source of phenol-degrading bacteria is peat soil, 
Khusnuryani et al.

because it contain high phenol, then bacteria with high ability in phenol degradation can be obtained from it.

\section{Biofilm Formation Test}

The ability to degrade phenol is not always parallel with the ability to form biofilm, and vice versa. Therefore, all isolates showed high potency to degrade phenol (18 isolates) were further selected for biofilm formation ability test (Figure 1).

According to Møretrø et al. (2003), ATA6 can be categorized as strong biofilm former, 12 isolates as medium biofilm former, and 5 isolates as weak biofilm former. Based on Figure 1, almost all isolates showed decreasing biofilm formation after 72 hours of incubation, except for HP3, ATA4, HG2, and SG2. However, biofilm-forming abilities of those four isolates were still categorized as medium (HP3, ATA4, HG2) or weak biofilm former (isolate SG2). Those up and down biofilm formation show that the biofilm formation can be fluctuated from time to time.

Microbes commonly live by forming biofilm. Bacteria grown in biofilm community
I.J. Biotech.

can perform some complex metabolic processes (Davey and O'toole, 2000). The ability to produce biofilm plays important role in environment, such as for bioremediation of hazardous wastewater, whether in industry or medical/clinical. In addition, biofilm may also function as biobarrier to protect soil and groundwater from contamination (Parsek and Fuqua, 2004).

Immobilized microbes are more effective in phenolic wastewater treatment and produce less sludge, while the usage of active cells in active sludge will lead to another problem, such as solid waste production (Ying et al., 2007). Moreover, biofilm matrix can protect the bacteria from environmental stresses and support bacterial cells to maintain their position for longer time than that in planktonic condition, and the metabolic interaction among bacteria will enhance the degradation process (Davey and O'toole, 2000; Flemming et al., 2000; Cerca et al., 2005; Andersson, 2009). Parsek and Fuqua (2004) also reported that biofilms played a role in wastewater treatment containing nitrogen and phosphor, also decreased

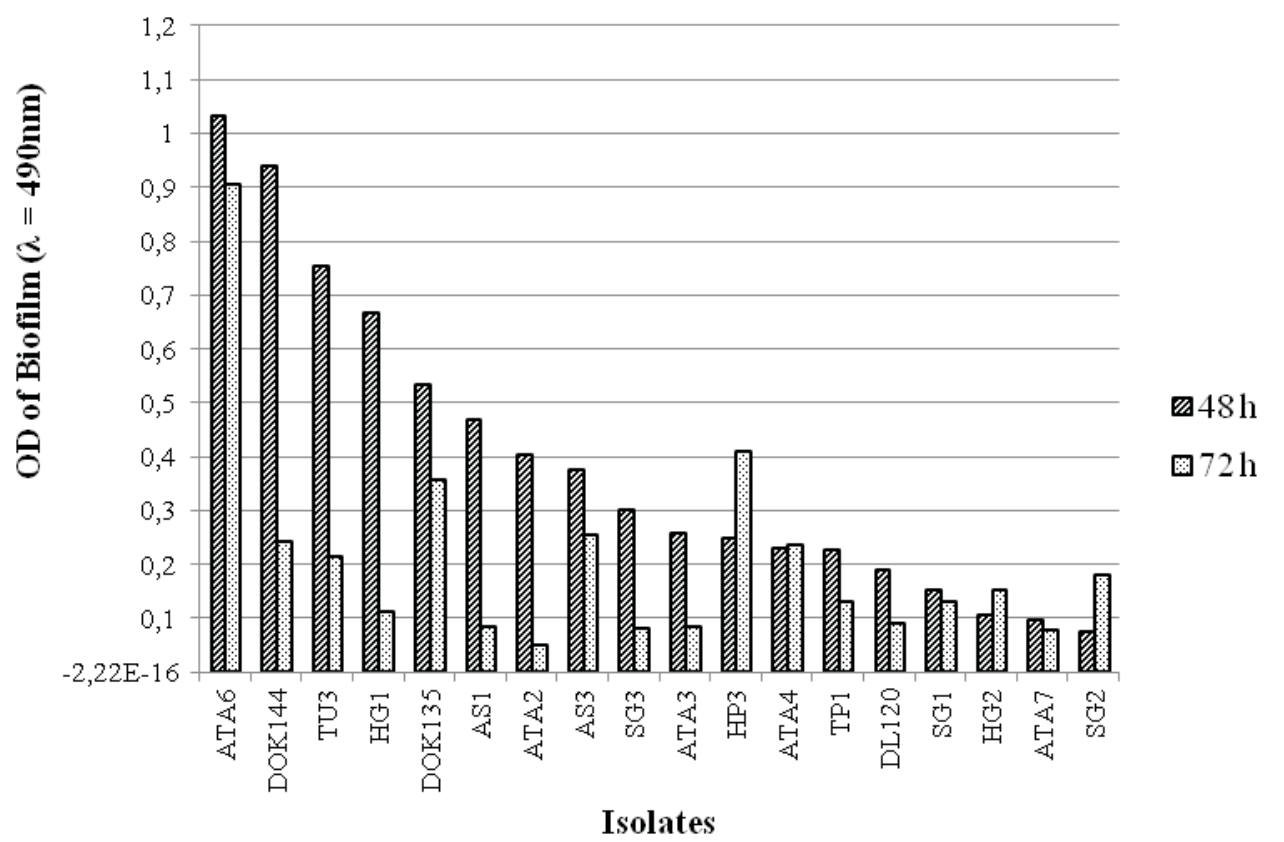

Figure 1. The Results of biofilm formation ability test by phenol-degrading bacteria in TSB medium, at $30^{\circ} \mathrm{C}$, and incubation time of 48 and 72 hours. 
COD or BOD. Therefore, phenol degrading bacteria which were obtained in this research were tested for biofilm formation ability.

Based on the ability to degrade phenol (Table 1) and to form biofilm (Figure 1), seven isolates (DL120, DOK135, ATA6, TU3, SG3, HP3, and HG1) were choosen as phenol-degrading bacteria as well as biofilm-forming bacteria. Six isolates (except ATA6) showed the highest ability to degrade phenol. Eventhough isolate ATA6 showed lower ability of phenol degradation than those six isolates, ATA6 demonstrated the highest ability of biofilm formation. On the contrary, DL120 that shown the highest ability in degrading phenol was identified as a weak biofilm former. Meanwhile, isolate DOK135, TU3, SG3, HP3, and HG1 were categorized as medium biofilm former. So, those seven isolates were selected for further test, including antagonism test among isolates to assess their growth ability in a mixed culture. Based on antagonism test (data not shown), DL120, DOK135, ATA6, and HP3 were choosen for characterization and identification.

DL120, DOK135, and ATA6 were obtained from hospital wastewater, while HP3 from peat soil. Those isolates were indigenous bacteria from source which contain phenol. The isolates also can form biofilm. Therefore, those isolates were predicted can survive when applied for phenolic wastewater treatment and can reduce the phenol effectively.

\section{Identification of Isolate DOK120, DOK135, ATA6, and HP3}

The four selected isolates were identified based on phenotypic character, including morphology of colony and cell, as well as biochemical characteristics. The characterization results were used as a basis to choose the representative species for molecular identification. The selection of representative species was conducted by profile matching analysis based on Bergey's Manual of Determinative Bacteriology (Holt et al., 1994). The result of profile matching analysis was shown in Table 2.

Based on profile matching analysis, ATA6 was suggested as a member of Genus Bacillus, because of some similar characters, such as rod-shaped cells, Gram positive, motile, aerob, and catalase-positive. On the other hand, isolate DOK135 had a rod shape, Gram negative, and motile. Based on those characters, DOK135 was predicted as a member of Genus Enterobacter. On the other hand, isolat HP3 showed some similar characters with Genus Rhodococcus. Those characters were cream colony with smooth structure, coccus cells, Gram positive, nonendospore-forming, catalase-positive and oxidase-positive. Meanwhile, isolate DL120 showed some characters such as yellow colony, coccus cells, Gram negative, motile, and catalase-positive. Those characters were similar with the key characters of Genus Micrococcus. To confirm the phenotypic identification, further identification based on $16 S$ rDNA was performed.

Table 3 showed similarity values and the result of nucleotide alignments between the selected isolates and the representative strains obtained from NCBI. The data indicated that isolate ATA6 could be classified to the genus of Bacillus because ATA6 was $100 \%$ similar with Bacillus subtilis strain DSM10. In addition, the number of matched nucleotides resulted from alignment between the two $16 \mathrm{~S}$ rDNA was $1411 \mathrm{bp}$ with no mismatched nucleotide. Likewise, the similarity of $100 \%$ was also shown between isolate HP3 and Rhodococcus equi strain DSM20307T with 1391 of matched nucleotides. Thus, it could be suggested that HP3 belonged to the genus of Rhodococcus. 
Khusnuryani et al.

I.J. Biotech.

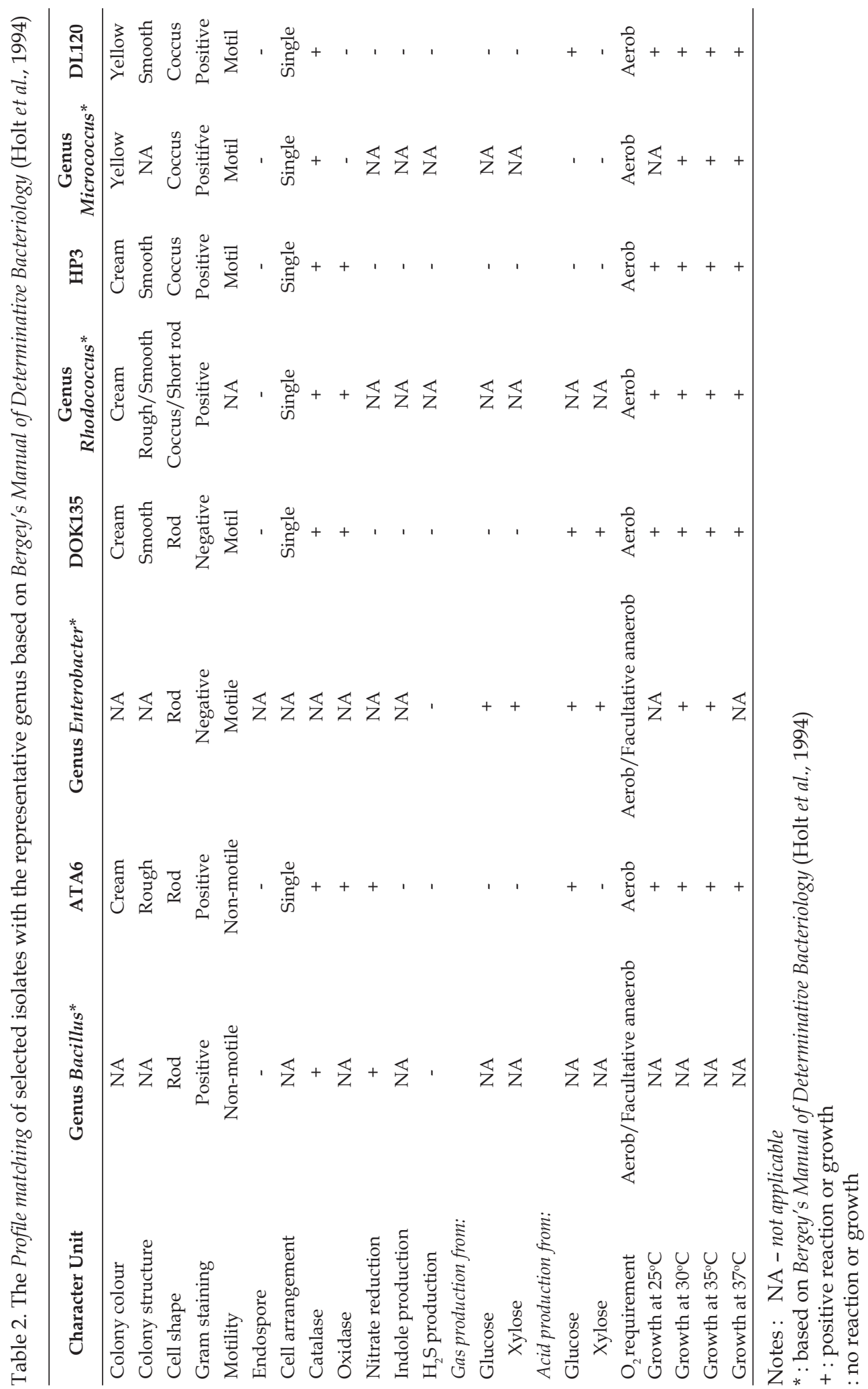


Khusnuryani et al.

I.J. Biotech.

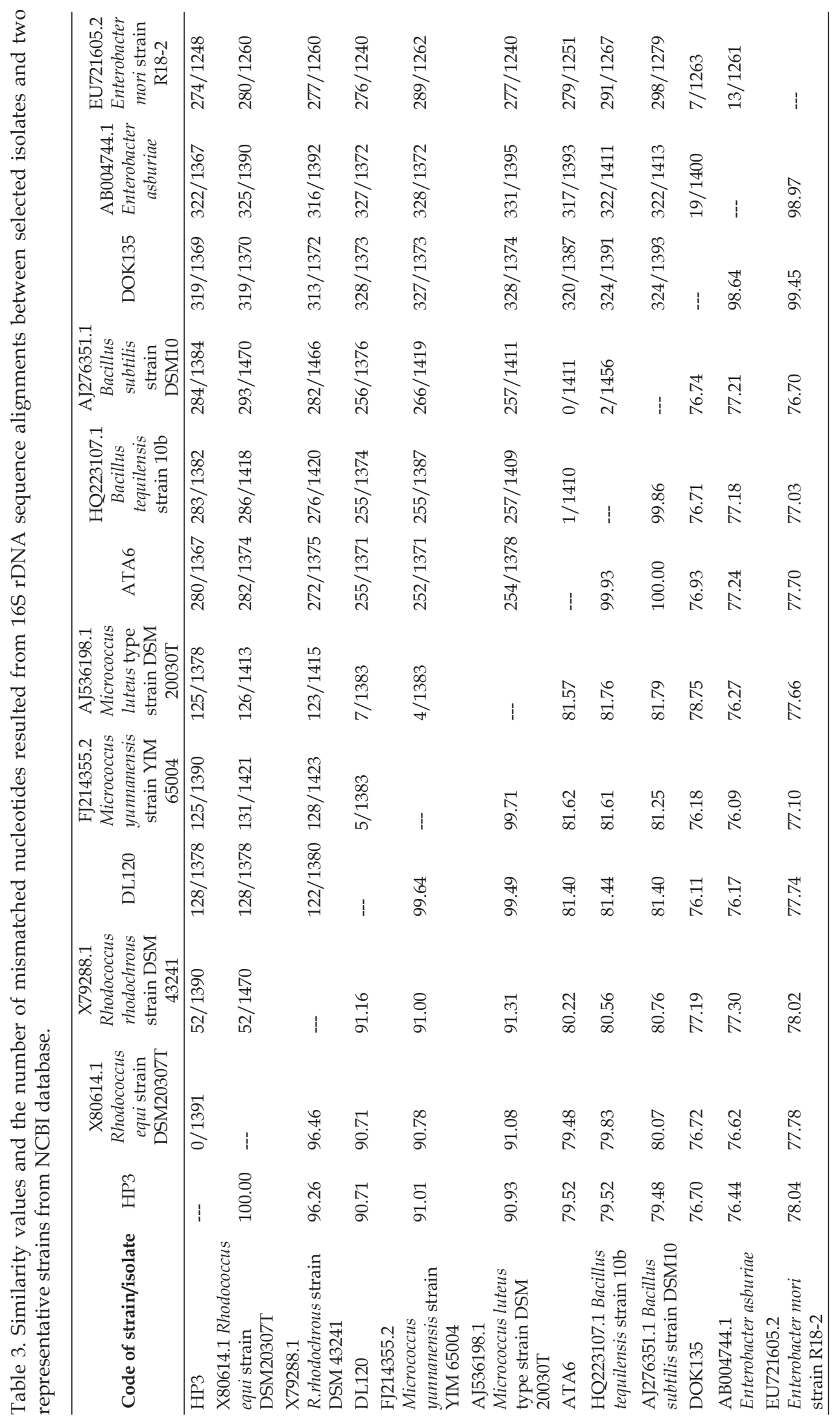


Khusnuryani et al.

Isolate DOK135 had similarity value of 98,64\% and 99,45\% with Enterobacter asburiae and E. mori respectively. There were 19 mismatched nucleotides (19/1400) between DOK135 and with E. asburiae, while out of 1263 nucleotides aligned, DOK 135 and E. mori had seven mismatched nucleotides (7/1263). Therefore, isolate DOK135 could be classified to the genus of Enterobacter. On the other hand, isolate DL120 had a highest similarity with Micrococcus yunnanensis strain YIM 65004 at 99,64\%, with five mismatched nucleotides out of 1383 nucleotides aligned.
I.J. Biotech.

The sequence analysis of those four isolates was in accordance with the profile matching results using Bergey's Manual of Determinative Bacteriology. Both profile matching and molecular analysis based on 165 rDNA were needed to confirm the results. In addition to similarity value and the alignment with representative strains, phylogenetic tree was also constructed to identify the clustering of isolates and representative strains (Figure 2). Phylogenetic tress was constructed by neighbor-joining method using DARwin5 programme.

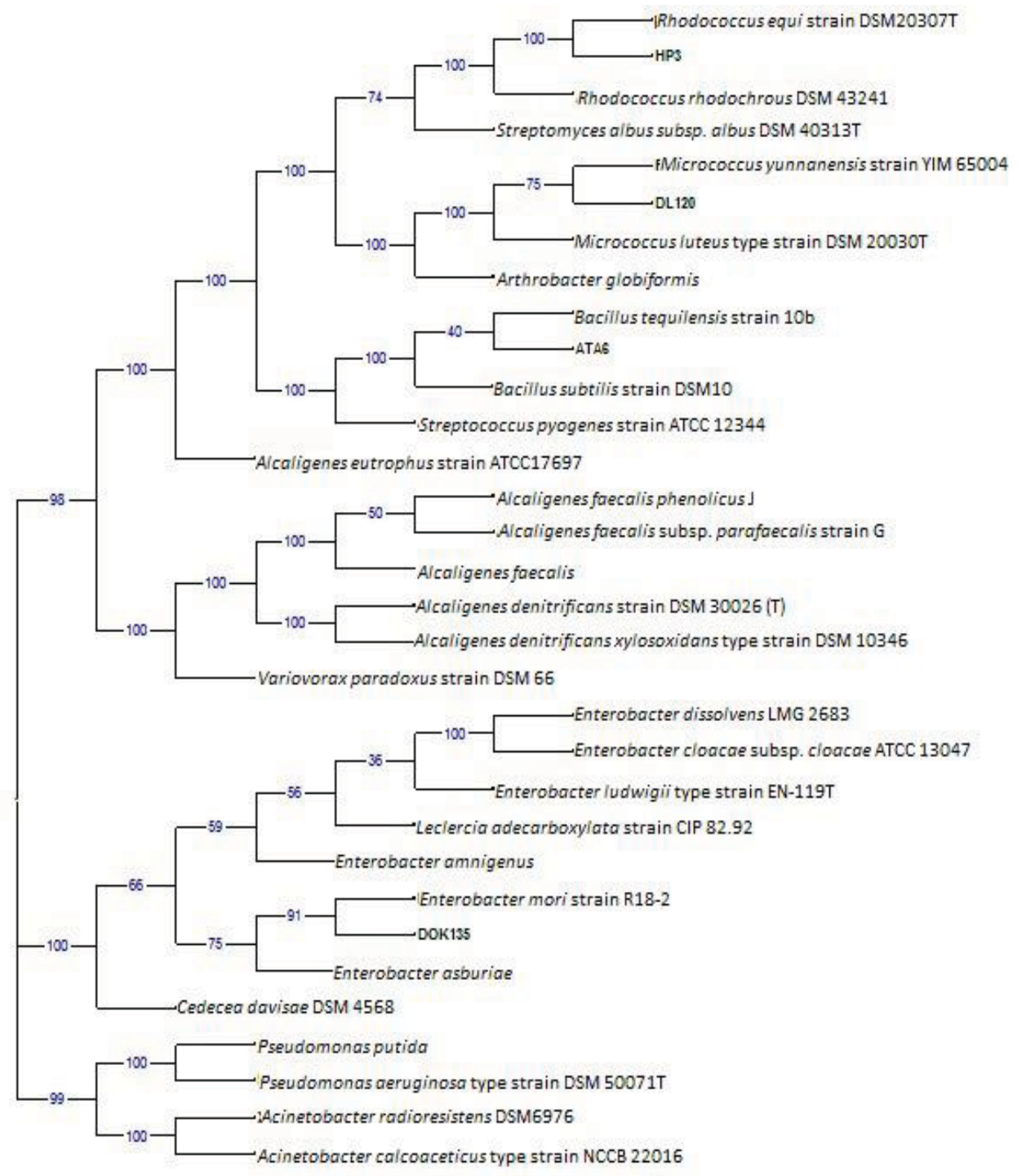

Figure 2. Phylogenetic tree of the isolated strains and the related species constructed by neighborjoining method. 
Khusnuryani et al.

The phylogenetic tree showed that isolates HP3 and Rhodococcus equi strain DSM20307T were clustered together with a strong bootstrap support of $100 \%$. According to Straube (1987), Rhodococcus sp was identified as phenol-degrading bacteria. In addition, Holt et al. (1994) revealed that genus Rhodococcus could be found in soil, and HP3 was isolated from peat soil.

Isolate DL120 formed a clade with two representative strains (Micrococcus yunnanensis strain YIM 65004 and Micrococcus luteus type strain DSM 20030T) with a strong bootstrap support of $100 \%$. The results of the phylogenetic analysis strongly suggested that DL120 belonged to the genus of Micrococcus. Moreover, Tibbles and Baecker (1989) also reported that Micrococcus sp was able to degrade phenol.

Isolate ATA6 was clustered together with Bacillus tequilensis strain $10 \mathrm{~b}$ and Bacillus subtilis strain DSM10 with a strong bootstrap support of $100 \%$. However, ATA6 and Bacillus tequilensis strain $10 \mathrm{~b}$ formed a clade with a weak bootstrap support of $40 \%$. Regardless, it could be inferred that ATA6 was a member of Bacillus, as such a study by Al-Thani et al. (2007) that suceeded to isolate phenoldegrading bacteria that similar to genus of Bacillus. In contrast with ATA6, DOK135 formed a clade with Enterobacter mori strain R18-2 with a strong bootstrap support of 91\%, but they grouped together with Enterobacter asburiae at a lower bootstrap support of $75 \%$. According to Holt et al. (1994), the member of Bacillus can be found in several habitats, while the member of Enterobacter can be found in freshwater, soil and wastewater. Both DL120 and DOK135 were isolated from hospital wastewater.

\section{Conclusion}

The analysis identified four phenoldegrading and biofilm-forming bacteria that could be classified into four different genus. Isolate HP3 was highly similar to Rhodococcus equi strain DSM20307T, while DL135 was higly similar to Enterobacter mori
I.J. Biotech.

strain R18-2.On the other hand, the results strongly suggested that DL120 and ATA6 could be classified to the genus of Micrococcus and Bacillus respectively.

\section{References}

Agarry, S.E., Audu, T.O.K., and Solomon, B.O. 2009. Substrate Inhibition Kinetics of Phenol Degradation by Pseudomonas fluorescence from Steady State and Wash-out Data. Int. J. Environ. Sci. Tech., 3, 443-450.

Agus, F. and Subiksa, I.G.M. 2008. Lahan Gambut: Potensi untukPertanian dan Aspek Lingkungan. Bogor: Balai Penelitian Tanah dan World Agroforestry Centre (ICRAF).

Al-Thani, R.F., Desouky A.M.A., and Mona A. 2007. Isolation, Biochemical and Molecular Characterization of 2-chlorophenoldegrading Bacillus Isolates. Afr. J. Biotechnol., 23, 2675-2681.

Amro, A.A. and Soheir, S.R. 2007. Characterization of PHA Depolymerase in Phenol Degrading Bacteria, International Journal of Biotechnology \& Biochemistry (internet), <http:// www.thefreelibrary.com $>$ (accessed 5 Januari 2009).

Andersson, S., Nilsson, M., Dalhammar, G.and Rajarao, G.K. 2008. Assessment of Carrier Materials for Biofilm Formation and Denitrification. Vatten, 64, 201207.

Andersson, S. 2009. Characterization of Bacterial Biofilms from Wastewater Treatment. Stockholm: Royal Institute of Technology, School of Biotechnology.

Anonim. 2008. Toxicological Profile for Phenol, Atlanta: ATSDR (Agency for Toxic Substances and Diseases Registry) U.S. Department of Health and Human Services.

Aoyama, A., Hojo, H., Takahashi, K.L., Shimizu-Endo, N., Araki, M., Takeuchi-Kashimoto, Y., Saka, M., and Teramoto, S. 2012. Two-generation Reproduction Toxicity Study in Rats 
Khusnuryani et al.

with Methoxychlor. Congenit. Anom., $52,28-41$.

Barchia, M.F. 2006. Gambut: Agroekosistem dan Transformasi Karbon. Yogyakarta: Gadjah Mada University Press

Bayoumi, R.A. and Ashraf T.A. 2010. Optimization of Bacterial Biodegradation of Toluene and Phenol Under Different Nutritional and Environmental Conditions. J. Appl. Sci. Res., 8, 10861095.

Bitton, G. 2005. Wastewater Microbiology. New York: John Wiley \& Sons

Cerca, N., Pier, G.B., Vilanova, M., Oliveira, R., and Azeredo, J. 2005.Quantitative Analysis of Adhesion and Biofilm Formation on Hydrophilic and Hydrophobic Surfaces of Clinical Isolates of Staphylococcus epidermidis. Res. Microbiol.,156, 506-514.

Chakraborty, S., Bhattacharya, T., Patel, T.N., and Tiwari, K.K. 2010. Biodegradation of Phenol by Native Microorganism Isolated from Coke Processing Wastewater. J. Environ., Biol., 31, 293296.

Davey, M.E. and O'toole, G.A. 2000. Microbial Biofilms: from Ecology to Molecular Genetics. Microbiol. Mol. Biol. Rev., 64, 847-867.

Djordjevic, D., Wiedmann, M., and McLandsborough, L.A. 2002. Microtiter Plate Assay for Assessment of Listeria monocytogenes Biofilm Formation. App. Environ. Microbiol., 68, 2950-2958.

Dumitru, A., Morozan, A., Ghiurea, M., Scott, K., and Vulpe, S. 2008. Biofilm Growth from Wastewater on MWNTs and Carbon Aerogels. Phys. Status Solidi (a)., 205, 1484-1487.

El-Sayed, W.S., Ibrahim, M.K., Abu-Shady, M., El-Beih, F., Ohmura, N., Saiki, H., and Ando, A. 2003. Isolation and Characterization of Phenol-catabolizing Bacteria from a Coking Plant. Biosci. Biotech. Biochem., 67, 2026-2029.

Flemming, H., Wingender, J., Griebe, T., and Mayer, C. 2000. Physico-chemical
I.J. Biotech.

Properties of Biofilms. In Biofilms: Recent Advances in their Study and Control (L.V. Evans, ed.). pp. 19-27. Amsterdam: Harwood Academic Publishers.

Holt, J.G., Krieg, N.R., Sneath, P.H.A., Staley, J.T., and Williams, S.T. 1994 Bergey's Manual of Determinative Bacteriology 9nd ed. Baltimore: Williams and Wilkins.

Khuanmar, K., Wanpen, W., Puangrat, K., and Santi, M. 2007. Photocatalysis of Phenolic Compounds with Synthesized Nanoparticles $\mathrm{Tio}_{2} / \mathrm{Sn}_{2}$. J. Appl. Sci., 14, 1968-1972.

Lee, M., Lee, W., Kam, S., Lee, D., and Hano, T. 1997. Treatment of Hospital Wastewater by Biological Fluidized Bed. Appl. Chem., 2, 526-529.

Mahiuddin, Md., A.N.M. Fakhruddin, and Abdullah-Al-Mahin. 2012. Degradation of Phenol via Meta Cleavage Pathyaw by Pseudomonas fluorescens PU1. ISRN Microbiology. Vol. 2012.

Mailin, M. and Firdausi, R. 2006. High Performance Phenol Degrading Microorganisms Isolated from Wastewater and Oil-Contaminated Soil. Malays. J. Microbiol., 2, 32-36.

Martinez, L.R. and Casadevall, A. 2007. Cryptococcus neoformans Biofilm Formation Depends on Surface Support and Carbon Source and Reduces Fungal Cell Susceptibility to Heat, Cold, and UV Light. Appl. Environ. Microbiol., 73, 4592-4601.

Mathur, T., Singhal,S., Khan, S., Upadhyay, D.J., Fatma, T., and Rattan, A. 2006. Detection of Biofilm Formation Among Clinical Isolates of Staphylococci: an Evaluation of Three Different Screening Methods. Indian J. Med. Microbiol., 24, 25-29.

Merritt, J.H., Kadouri, D.E., and O'Toole, G. 2011. Growing and Analyzing Static Biofilms, Current Protocols in Microbiology, John Wiley \& Sons, Inc.

Mohite, B.V., Ruby, E.J., Shradha, P., and Ankush, M. 2010. Isolation and Characterization of Phenol Degrading 
Khusnuryani et al.

Bacteria from Oil Contaminated Soil. Innov. Rom. Food Biotechnol., 7, 61-65.

Møretrø, T., Lene, H., Askild, L.H., Maan, S.S., Knut, R., and Solveig, L. 2003. Biofilm Formation and the Presence of Intercellular Adhesion Locus icaStaphylococci from Food and Food Processing Environments.Appl. Environ. Microbiol., 69, 5648-5655.

Movahedyan, H., Khorsandi, H., Salehi, R., and Nikaeen, M. 2009. Detection of Phenol Degrading Bacteria and Pseudomonas putida in Activated Sludge by Polymerase Chain Reaction. Iran. J. Environ. Health Sci. Engin., 6, 115-120.

Parsek, M.R. and Fuqua, C. 2004. Biofilm 2003: Emerging Themes and Challenges in Studies of Surface-Associated Microbial Life (Meeting Review). J. Bacteriol., 186, 4427 - 4440

Straube, G. 1987. Phenol Hydroxylase from Rhodococcus sp. P1. J. Basic Microbiol., 27, 229-232.

Tibbles, B.J. and Baecker, A.A.W. 1989. Effects and Fate of Phenol in Simulated Landfill Sites. Microb. Ecol., 17, 210-206.

Tsai, S., Tsai, L., and Li, Y. 2005. An Isolated Candida albicans TL3 Capable of Degrading Phenol at Large Concentration. Biosci. Biotech. Biochem., 69, 2358-2367.

Tuah, P.M., Rashid, N.A.A., and Salleh, M.Md. 2009. Degradation Pathway of Phenol through Ortho-Cleavage by Candida tropicalis RETL-Cr1. Borneo Sci., 24, 1-8.

Van Schie, P.M. and Young, L.Y. 1998. Isolation and Characterization of PhenolDegrading Denitrifying Bacteria. Appl. Environ. Microbiol., 64, 2432-2438.

Vermerris, W. and Nicholson, R. 2006. Phenolic Compound Biochemistry. Netherlands: Springer.

Vogel, T.M. and Michael, V.W. 2002. Bioaugmentation. In Manual of Environmental Microbiology second edition (C.J. Hurst, R.L. Crawford, M.J. McInerney, G.R. Knudsen, and
I.J. Biotech.

L.D. Stetzenbach, eds.) pp. 952-959. Washington D.C.: ASM Press.

Wang YD, Dong XJ, Wang X, Hong Q, Jiang $X$, and Li SP. 2007. Isolation of PhenolDegrading Bacteria from Natural Soil and Their Phylogenetic Analysis. Huan Jing Ke Xue, 28, 623-626.

Watanabe, K., Maki T., Hiroyuki F., and Shigeaki H. 1998. Molecular Detection, Isolation, and Physiological Characterization of Functionally Dominant Phenol-Degrading Bacteria in Activated Sludge. Appl. Environ. Microbiol., 11, 4396-4402.

Ying, W., Ye, T., Bin, H,Hua-bing, Z., Jian-nan, B., and Bao-li, C. 2007. Biodegradation of Phenol by Free and Immobilized Acinetobactersp strain PD12. J. Environ. Sci., 19, 222-225.

Yoshida, S., Ogawa, N., Fujii, T., and Tsushima, S. 2009. Enhanced Biofilm Formation and 3-chlorobenzoate Degrading Activity by the Bacterial Consortium of Burkholderia sp. NK8 and Pseudomonas aeruginosa PAO1. J. Appl. Microbiol., 106, 790-800.

Zaki, S. 2006. Detection of Meta- and OrthoCleavage Dioxygenases in Bacterial Phenol-Degraders. J. Appl. Sci. Environ. Manage., 10, 75 - 81. 